\title{
DIE WERK VAN DIE PREDIKANT *
}

\section{INLEIDING.}

Dit is te alle tye vir die Kerk saaklik en sinvol om tc besin oor sy werk in die wêreld.

Aan die hand van die Kerkwet, Hoofstuk XV van die Bepalings, artikel 1 en 2 (bladsy 60), wil ons nou só gaan nadink oor die predikant en sy werk, dat ons tot helderheid oor die vraag kan kom of ons, ons werk wel doen en dit ook reg doen.

\section{ARTIKEL 1 :}

is vir ons hier bloot van belang omdat die werk van die predikant onderskei word in gewone en besondere werk. Dit beteken dat daar vir ons Kerk predikante in gewone diens en predikante in besondere diens is. D.w.s. dat daar verskillende groepe van persone kan wees, wat die status van predikant beklee. Dit bring sekere vrae na vore. En op een of ander wyse sal hierdie vrae beantwoord moet word. Die eintlike vraag wat ons hier wil stel is die vraag na die verhouding tussen hierdie verskillende groepe van predikante na aanleiding van die verskillende hoofklemme wat op hulle werk gelê word.

*) Lesıng gehou voor die Predikantevergadering, 19 September 1962. 


\section{(a) Die missionêre leraar:}

Ons ken nie 'n sendeling nie. Ons sendingbeleid laat so-iets nie toe nie. Tog was daar al 'n missionêre leraar in Angola. Aan hom was al die gewone take toevertrou wat enige predikant moet behartig. $\mathrm{Hy}$ was egter blykbaar in terme van Artikel 8 van die Dortse kerkorde op grond van singuliere gawes toegelaat tot hierdie amp sonder die vereiste voorstudie. Vervolgens was sy bevoegdhede aan hom verleen slegs vir Angola. Daarbenewens was hy 'n blanke en sy lidmate blankes. Hulle - tenminste die oorgrote meerderheid van hulle - was gedoop en het belydenis van geloof gedoen. Bowendien het hulle - die uitsonderings daar gelate so goed of so sleg as wat die omstandighede dit toegelaat het, by hulle belydenis en die Kerk gebly.

Of ons dit wil weet of nie, ons gaan 'n toestand tegemoet waar ons sal moet begin dink aan die afsondering van predikante vir die werk onder die blanke heidendom. Die vraag is nou: Gaan hierdie presedent die patroon wees waarop daar gewerk gaan word in verband met missionêre werk onder blankes?

(b) Dosente vir die opleiding van nie-blanke leraars:

Dit is blykbaar 'n vereiste dat hierdie dosente volle predikantstatus moet hê in ons Kerk. Dit wil sê, aan hulle is toevertrou al die gewone werksaamhede van 'n predikant. Nou kom die probleem egter hierby dat hierdie mense eintlik gladnie hierdie werk in 'n blanke gemeente verrig nie. Kragtens ons sendingbeleid het hulle geen bevoegdheid om predikantswerk in 'n Bantoegemeente te verrig nie. Die verdere probleem is naamlik dat hulle werksterrein wel die Bantoekerk is vir wie hulle predikante oplei. En in ons Kerk kan niemand professor wees as hy nie predikant van die Kerk is nie. Hopelik is die toestand egter 'n tydelike saak. Maar dit mag selfs nog baie jare duur voordat die Bantoekerk hierdie werk self kan behartig. In die tussentyd sal hieraan iets gedoen moet word.

\section{(c) Predikante met 'n binnekerklike taak:}

$\mathbf{u}$

Hierdie predikante se hoofwerk sal in bepaalde gevalle in hoofsaak administratief wees. Tog sal hulle predikantsbevoegdheid hê. Op watter gronde kan dit gebeùr as byvoorbeeld 'n missionêre leraar se bevoegdhede heeltemaal beperk was tot die gebied waarheen hy gestuur is?

\section{ARTIKEL 2:}

Die opskrif hierbo sê dat dit gaan om die werk van die predikant. Artikel 2 word ingelui met die woorde: „Die gewone werksaamhede word verrig in diens van 'n gemeente en omvat:...." 


\section{(a) Gemeente:}

Onder gemeente verstaan ons 'n groep van mense wat om verskillende redes georganiseer is tot 'n geografiese eenheid met een of meer predi. kantstandplase. So 'n gemeente omvat die belydende lidmate, die wat uit ander Kerke opgeneem is, die gedooptes en dié wat uit Hervormdz ouers gebore is (Artikel II van die Wet). Hierdie mense is die arbeidsveld van 'n gewone predikant.

\section{(b) In diens van 'n gemeente:}

Wat is die sin en doel van hierdie diens? Die formulier vir die bevestiging van predikante omskryf die doel van hierdie werk as daarin geleë dat die gemeente sal toeneem, ,in aantal en in deug”. Die Nuwe Testament self omskryf die doel van hierdie dienswerk ook só, naamlik dat die gemeente moet groei in getalle en toeneem in geloof (vergelyk $\mathrm{Hnd}$. $9: 31$; 16:4 en 5). Dit word dan saamgevat onder die begrip opbou (oikodomen). Ef. 4:13 en 14 gebruik die beeld van kinderopvoeding sodat die kind tot volle manlike rypheid kan kom (vgl. Heb. 6:1) om die doel van die amptelike dienswerk an die gemeente te omskrywe. Hierdie opbou van die gemeente word onderneem tot 'n eenheid van geloof en kennis van Christus; 'n standvastigheid teenoor dwaling en dwaalleraar; ' $n$ betragting van die waarheid in liefde; ' $n$ opgroei in die hoof Christus en 'n meelewe en meewerk van elke afsonderlike lid. Mat. 28:19(b) vat die doel van die gemeente-opbou saam in die woorde ". . . . leer hulle om alles te onderhou wat Ek julle beveel het". Die duidelike bedoeling van al hicrdie dinge is naamlik "dat elke knie sal buig en elke tong sal bely dat Christus Jesus die Here is tot heerlikheid van God die Vader" (Fil. 2:11).

As ons nou kan aanneem dat hierdie gemeente-opbou inbegrepe is by die woorde ,in diens van 'n gemeente", dan is in hierdie artikel ook vir ons die enigste legitieme gesigspunt waaronder amptelike dienswork in 'n gemeente verrig kan word, meegegee.

\section{(c) „Die gewone werksaamhede word verrig .....":}

Daar moet klem gelê word op die, ," ‘rrig". Die amp is 'n diakonia, die ampsdraer „diakonos” van Christus v." die gemeente (Kol. 1:25). In die navolgende sal dit moet gaan om $w_{1}:$ die predikant "doen" in die gemeente. Sy didaskein en poimainein (Mlt. 28:19(b); 1 Pet. 5:2; Joh. 21:16; Hnd. 20:28) laat die Kerk nie ma: sommer aan elkeen se eie willekeur oor nie, maar dit word in sekere bane gelei sodat dit in die Kerk ordelik daaraan sal toegaan. En nou glo ek dat dit die gedagte was van die bestuur van die predikanteverkadering toe hulle aan my die opdrag gegee het om te praat oor die werk van die predikant, om die lig te laat val op die voorgeskrewe werk van dic predikant. 
Volgens diẻ bepaling van die Kerkwet val die diens wat verrig moet word uiteen in twaalf onderafdelings wat m.i. net vyf moet wees omdat sommige van die onderafdelings onder een hoof tuisgebring kan en moet word. Ons onderskei die volgende vyf:

(i) die homiletiese werksaamheid. Dit omvat die verkondiging van die Woord en die bediening van die Sakramente.

(ii) Die leiding van die kerkdienste. Dit noem hierdie bepaling ongelukkig nie, terwyl art. 3 dit wel noem by die besondere werksaamhede van 'n predikant in besondere diens. Die bepaling noem egter wel besondere momente wat 'n predikant nie anders as in 'n erediens kan behartig nie, naamlik afneem van openbare gelo ibelydenis, bevestiging van ampsdraers, bevestiging en inseëning van huwelike. Hierin sien ons genoegsame rede om te praat oor die erediens.

(iii) Kategese en geestelike vorming van die jeug.

(iv) Herderlike sorg en hieronder sieketroos, opsig oor gemeente, arbeid onder dié wat van die Evangelie vervreemd is.

(v) Die leiding van die amptelike vergaderinge.

\section{DIE HOMILETIESE WERKSAAMHEID:}

Watson (Zielzorg en Herderlijkt Ambt, bls. 1) praat oor die werk met goeie reg as volg: ,.Het behoort tot de plichten van den Evangeliedienaar getrouw huisbezoek te doen; geen moeite te ontzien om den ere dienst schoon en stichtelijk te maken; alles in't werk te stellen om het godsdienstonderwijs der jeugd te doen beantwoorden; zijn gemeenteleden op te wekken tot al het goedf, wat hun hand vindt om te doen: maar wee hem als hij ooit vergeet dat de meest belangrijke en invloedrijke gebeurtenis in de kerkelijke week de preek is. Het getuigenis der historie laat in dezen opzicht geen twijfel over. Als de evangelieprediking gestaakt werd of in minachting geraakte, werd de kerk zwak en bedorven. Als de evangelieprediking haar aloude invloed herwon, ontwaakte de kerk en toog haar ,schoone gewaden" aan. Geen macht heeft by menschenheugenis zulke wonderen gewrocht als het gesproken woord...."

As ons nou gaan praat oor hierdie so verantwoordelike werk van die predikant, dan kan ons dit nie anders doen as op die basis van die heilige Skrif nie en dan geskied dit spesifiek teen die agtergrond van die Nieutestamentiese begrippe homilia, profeteia en paraklesis.

\section{Prediking is profetiese getuienis:}

Dit is die akte van bekendmaking en uitleg van Gods openbaring soos vir ons betuig in die Skrifte. As sodanig is dit getuienis aangaande Jesus Christus se persoon en Sy werk teen behoewe van mense (vgl. Op. 
19:10; Hand. 8:28-35; Luk. 24:27 en 44). As prediking werklik prediking wil wees, dan moet dit Christusprediking wees.

Dit kan egter nooit 'n spekulaticwe spreke van die mens uit „oor" Christus of watter onderwerp ookal wees nie. Dit moet altyd spreke wees om Christus ontwil en in Sy Naam (I Kor. 1:10; 2 Kor. 5:20; I Tess. $4: 1$ ). Daarom kan die prediking nooit deur 'n blote veelvuldige gebruik van die Naam van Jesus Christus werklik Christus-prediking word nie, omdat dit so van Hom moet spreek dat $\mathrm{H}_{\text {yself }}$ in die gesproke woord van die prediking aan die woord kom en sy woord tot sy mense kan rig, volgens sy eie belofte in Luk. 10:16;

„Wie julle hoor, hoor My! Slegs langs hierdie weg kom dit tot prediking waardeur die hoorders gestel word voor die keuse: „Vir Christus of teen Hom". Daarom kan die prediking nooit 'n opstel oor 'n teks wees nie, maar die preek moet die gemeente aanspreek met die teks. bonde.

En juis om hierdie rede is die prediking inhoudelik en formeel ge-

(a) Inhoudelik is die prediking gebonde aan die Bybelse getuienis aangaande Jesus Christus, want die Skrifte getuig van die Christus (Luk. 24:25 en 24; Joh. 5. 39; Hnd. $8: 35$ en $18: 28$ ). Daarom kan ons sê dat prediking niks anders is as uitleg en toepassing van 'n teks of 'n perikoop nie. Hiervan het ons ook pragtige voorbeelde in die Bybel self. Bv. in Luk. $24: 24$ vervolgens, waar niemand anders as die Here Jesus Christus self begin met uitleg van die Skrif wat getuienis gee van Hom nie. Ons kan egter nie ons prediking en dié van Jesus sonder meer op een lyn stel nie. Ons het egter ook voorbeelde in die Bybel van die prediking van mense wat ook die weg volg van uitleg van die Bybel, bv. die Pinksterprediking van Petrus. Daar gee hy uitleg van die profesie van Joël en die Psalms van Dawid. En by die aanhoor daarvan is die hoorders diep in die hart getref (Hnd. 2:37). Ook die prediking van Philippus aan die kamerling is uitleg van die Skrifte. In geen geval was dit ongekwalifiseerde uitleg nie, maar wel uitleg met betrekking tot Christus. Dit wil sê: Die plek waar die predikant in sy profetiese predikingswerk die boodskap verneem wat hy moet oorbring, is die Bybel. Want as hy werklik profeties werksaam wil wees dan staan dit vir hom vooraf vas dat dit nie sy eie boodskap is wat hy moct oorbring nie maar die boodskap wat hom van Godsweë gegee word as Godsboodskap aan God se mense. Hy moet die Skrifte beluister om daarin sy boodskap te verneem. Hieraan is twee voorwaardes verbonde:

(i) Die Skrif is die beste verklaarder van die Skrif. Beter sou dit miskien wees om te sê die Bybel i.p.v. die Skrif, want dan skakel ons daarmee dadelik die misverstand uit asof 'n teks reg uitgelê kan word deur ' $n$ artikel uit die Huisgenoot of Readers Digest, wat geskrywe was 
sonder enige pretensie om so 'n teks te verklaar. Die punt waarom dit in hierdie betoog gaan is dit: 'n Baie goeie kennis van die Skrif is 'n noodsaaklike voorvereiste vir regte prediking (Hnd. 17:11; Rom. 4:3; Rom. 16:25 en 226; 2 Tim. 3:14-16).

(ii) Die tweede voorwaarde is ondersoek en navorsing na wat die bedoeling van die Heilige Gees was (I Petr. 1:11) met dié spesifieke woorde wat in die Skrifte geskrywe staan deur die heilige outeurs ,nie vir hulle self nie maar vir ons" (I Petr. 1:12). Hierdie saak behoef geen verdere betoog as ons luister na wat 2 Petr. 1:19-21 sê nie. Ek haal dit woordeliks hier aan vanweë die belangrikheid daarvan: „Want ons het die profetiese woord wat baie vas is, waarop julle tog moet ag gee soos op 'n lamp wat in 'n donker plek skyn, totdat die dag aanbreek en die môrester opgaan in julle harte; terwyl julle veral dit moet weet, dat al die profesieë van die Skrif nie 'n saak van eie uitlegging is nie; want geen profesie is ooit deur die wil van 'n mens voortgebring nie, maar, deur die Heilige Gees gedrywe het die heilige mense van God gespreek".

In die lig van hierdie twee voorwaardes is dit onontwykbare eis van 'n Bybelse prediking dat ons predikante baie meer sal moet studeer as ons die Skrif en die bedoeling van die Gees só wil ken dat ons verantwoord kan preek. Daar moet reg gepreek word. Dan word mense in die hart getref. En as daar verkeerd gepreek word, word die Kerk afgebreek. Ons moet ons ook bekla omdat Grieks III afgeskaf is. Dit sou eerder reg wees as Hebr. III bygevoeg word. Die tale is nodig as ons die Skrif wil verstaan.

Omdat 'n eiesinnige omgang met die Skrif afstuur op 'n verkeerde aanwending van die Skrif (vgl. Bigg in I.C.C. St. Peter en St. Jude, bls. 269 laaste paragraaf tot bl. 270 eerste paragraaf) en afbreking van die geloof, is die prediking materieël gebonde aan die leer as sy gids en die aanduiding van sy grense. Die leer het betrekking op Jesus Christus en op Gods Woord (Hnd. $8: 11 ; 18: 25$; en $28: 31$ ). En hierdie betrekking is so deurslaggewend dat iemand wat iets anders leer en nie instem met die „.... gesonde woorde van ons Here Jesus Christus en die leer wat volgens die godsaligheid is nie"... . as verwaand en niks-verstaande bestempel word [I Tim. 6:3 en 4(a) ]. En hierdie leer staan vir ons $1, \mathrm{~g}$ die suiwerste geformuleer soos dit vervat is in ons Belydenisskrifte.

Hierby net "n enkele opmerking oor die sg. "kategismuspreke". Die benaming "kategismuspreek" is in die lig van lg. "n contradictio in terminis. Die Skrif kan gepreek word, maar nie die belydenis nie. Skrif en belydenis is nie gelyk nie. Daarom is dit die hartlikste teenspraak wat mens kan bedink, wanneer daar beweer word, dat elke preek 'n kategismuspreek is, want dan word Skrif en belydenis sonder meer gelykgestel. Nog erger is dit wanneer by 'n kategismuspreek, 'n teks opgegee word en die 
bepaalde sondagsafedeling gebruik word as uitleg van die teks. Dan word die Skrif ondergeskik gemaak aan die belydenis en in die lig van die belydenis uitgelê, terwyl die Kerkwet vereis dat die belydenis uitgelê moet word in die lig van die Woord. Die baie besware wat gemaak word teen die uitleg van die belydenis in die gemeente openbaar 'n vrysinn'ge neiging waarteen ernstig gewaarsku moet word.

Wanneer daar in die prediking rekening gehou word met hierdie beperkings en voorwaardes, dan mag ons ook werklik hoop dat die Heilige Gees ons prediking sal gebruik as oproep tot die geloof en die volharding in die geloof in Jesus Christus.

(b) Formeel is die prediking ook gebonde. As profetiese oordrag van die ontvange boodskap moet dit sinvolle spreke-tot-mense wees (I Kor. 14:3, vgl. B. J. Engelbrecht, Proefskrif bl. 7). Die prediking kom nooit in 'n lugleegte nie. Dit is altyd gerig tot mens in ' $n$ konkrete situasie. Dit word gerig tot mense met die bedoeling om die gemeente op te bou (vgl. Hnd. 9:31) sodat die liggaam van Christus tot volle manlike rypheid ge. bring sal word en in die geloof sal volhard (I Kor. 14:22; Ef. 4:1; I Tim. $2: 1-3$ en Judas 3 ).

Die eis dat die preek 'n sinvolle spreke-tot-mense moet wees bring mee:

(i) Dat die preek 'n sinvolle eenheid moet vorm. As die prediker self die boodskap van sy teks verneem, verstaan en verwerk het, dan sal sy preek so 'n sinvolle geheel kan uitmaak. Verder laat ek nou vir Watson met twee sitate oor hierdie saak spreek: „De preek moet zijn een monographie en niet een encyclopaedie, een handelshuis voor één artikel en niet een toko waar men van alles kan koopen van een knoop af tot een doodskist" (bls. 11). In verband hiermee is daar volgens Watson drie grade van welsprekende predikante: „.... de prediker beneden pari, die een uur lang kan praten zonder één enkele idee; de prediker boven pari die een uur lang kan bekoren met een schittering van ideën; en de prediker juist a pari die in iets minder dan veertig minuten zich plichmatig beperkt tot één idee!" (bladsy 12).

(ii) Planmatigheid in die preekwerk. Hier lê twee weë oop: (a) Die strakke lectio continua en praedicatio continua wat Calvyn gevolg het of (b) prediking aan ciie hand van die kerklike jaar.

(a) Calvyn het by Gen. 1 begin en ongeag enigiets anders regdeur gepreek.

(b) Prediking aan die hand van die Kerklike jaar. Dit is die weg wat ons Kerkwet gaan. Dog hier is dit egter nog nie vir die predikant oopgelaat om maar tekste te kies soos 'n hoender mieliepitte oppik nie. Planmatigheid is hier nog 'n vereiste. Daaronder verstaan ons: Die 
prediking oor verskillende onderwerpe moet so behartig word, dat daar agtereenvolgens oor die verskillende aspekte van so 'n onderwerp gepreek word, sodat die gemeente uiteindelik 'n geheelbeeld van die bepaalde saak kan hê.

So 'n planmatigheid word vereis as die volgende oorweginge tot gelding kom. Die hele Skrif moet tot kennis van die gemeente gebring word in die prediking anders gaan ons soos die sektes om met die Skrif. Die hele raad van God moet verkondig word en van niks wat nuttig is mag iets nagelaat word nie, want die goddelike boodskap is geen onvoltooide, onsamehangende, onvolledige boodskap nie. Dit is juis die sinvolheid van die boodskap wat vereis dat die prediking sinvolle spreke-totmense moet wees.

(iii) Die predik'ng moet rekening hou met die konkrete situasie waarin die hoorders lewe. Die situasie moet in al sy fasette bekend wees by die prediker. Hierdie bepaling hoef egter nie so absoluut opgeneem te word as wat die negerpredikant in koue Alaska dit gedoen het nie. Hy het in ' $n$ preek vir sy gemeente vertel dat dit in die hel nog kouer is as in Alaska. Toe 'n kollega hom vra waarom hy die Skrif so verdraai was sy nugtere antwoord: As my gemeente weet dat dit warm is in die hel, sal hulle almal graag daarheen gaan! Wat wel bedoel word is, dat die predikant die situasie só moet ken dat sy prediking uitkom by die mense in die situasie waarin hulle hul werklik bevind. Dit is waar dat Gods trou van geslag tot geslag bly bestaan, maar ons moet aan "hierdie geslag” die evangelie preek.

(iv) ' $n$ Vierde vereiste is verstaanbaarheid: Hiervoor is prediking in die moedertaal seker baie nodig, alhoewel daar tog in bepaalde gevalle ook ander moontlikhede kan wees (N.B. Vgl. Kerk en Taal, in jongste Jaarboek voor de Eredienst). Vervolgens: verstaanbaarheid word geskaad deur die gebruik vandag van die tale Kanaäns of argaïstiese filosofiese terminologie van die Aufklärung op ons kansels. Andersyds hoef ons ook nie skokkend-vulgêre kontemporêre taal op die kansel te besig nie. Die bybelse terminologie, indien nugter en saaklik verduidelik, dien nog altyd daartoe dat Hy die Timmerman van Nasareth vandag ook deur die timmermans van ons tyd as Heer en Meester geken en bely kan word.

Met alles wat tot hiertoe gesê is, het dit seker al duidelik geword dat die prediking interimsbedeling is (I Kor. 13:8) - God se "troos". woord vir ons hier in "die tyd tussen die tye" wat verrig word in afwagting van die groot dag wanneer die profesieë in teenwoordigheid van die Groot Profeet sal ophou. Dit het seker ook duidelik geword dat dit onvolmaak is (I Kor. 13:9).

Tog mag dit nie veronagsaam en verwaarloos (I Tim. 4:14) of verag 
word nie (I Tess 5:20) nóg deur die predikant wat hierdie taak as gawe ontvang, nóg deur die gemeente in wie se diens dit verrig word nie.

Aangesien die prediking waaraan die Sakramente as Gods „troos”, tekens verbind is (H.K. Sondag 25) binne die gemeentelike erediens verrig word (Hand. 2:42; 20:7 en 11; I Kor. 14:3, 24 en 25) is dit nodig om ook te praat oor -

\section{DIE LEIDING VAN DIE KERKDIENSTE (Die Predikant as Liturg) :}

Vooraf moet daarop gewys word dat artikel 1 onder die gewone werksaamhede nie die leiding van die kerkdienste noem nie, terwyl dit wel genoem word onder die besondere werksaamhede in art. 3. Dit lyk vir my na ' $n$ fout. Dit behoort ook in art 2 genoem te word. Verder word daar drie dinge genoem as take van die predikant wat hy nie anders kan verrig as in gewone of buitengewone eredienste van die gemeente nie. Hierdie drie is naamlik: die afneem van die openbare geloofsbelydenis in die om. gang bekend as bevestiging van nuwe lidmate; bevestiging van kerkraads lede; die inseëning en bevestiging van huwelike. Opvallend genoeg word die leiding van die begrafnisdienste nie vermeld as taak van die predikant nie. Sou die opstellers van die Kerkwet dit nie gesien het as diens van die Woord nie of moet dit nie gesien word as diens van die Woord wat spesifiek deur die predikant verrig moet word nie? M.i. is die begrafnisdiens belangrik, want daar kom gewoonlik in hele klomp mense wat eintlik buitekerklik is.

Hoe dit ookal sy, die aanduidinge wat art. 2 hier gee is voldoende om hier te kan spreek oor die predikant as Liturg.

Die gemeentelike erediens dra die karakter van gesprek tussen God en Sy gemeente. In hierdie gesprek beklee die liturg 'n dubbele funksie. $\mathrm{Hy}$ moet optree as mondstuk van God by die volk. Dit doen hy as homileet. Tweedens moet hy optree as leier van die gemeentelike antwoord op die Woord. Dit doen hy wanneer hy vóórbid sodat die gemeente in die hart kan saambid en wanneer hy bepaal wat tydens die erediens gesing moet word. Opmerklik in hierdie verband is dat daar in ons kerk een deel van die Woordbediening, naamlik die wetlesing en een deel van die leiding van die gemeentelike antwoord, naamlik die geloofsbelydenis, toevertrou word aan ' $n$ ouderling. In feite kom dit daarop neer dat daar twee liturge optree in die een erediens. Hoe dit geregverdig moet word bly vir my in probleem. Of die wetlesing gesien moet word as 'n deel van die opsigtaak van die ouderlinge is vir my beslis nie duidelik nie. En om te beweer dat dit die ouderlinge se aandeel is aan die erediens is vir my heeltemaal onsinnig. Amptelik is die ouderling se aandeel aan die erediens soos in die Kerkwet bepaal: die byeenvergader van die gemeente vir die erediens, die opsig oor die goeie orde tydens die diens en om te 
waak oor die leer wat daar verkondig word en die suiwere bediening van die sakramente. Die gevaar van hierdie optrede van twee liturge is dat die erediens se eenheid versteur word en verder ook maklik deur die gemeente gesien kan word as 'n drama wat opgevoer word deur ampsdraers waarby hulle die toeskouers mag wees. Dit verbaas daarom ook gladnie dat ons gemeentes dit al mooi kan noem wanneer die predikant en orrelis byvoorbeeld met Kersfees 'n ,kersopera" hou in plaas van 'n Kersdiens!

Om terug te keer tot die predikant as liturg: Die konstituerende elemente van die erediens is die regte prediking van die Woord en die suiwer bediening van die Sakramente. As die predikant hierin misgetas het, dan het hy sy eerste en vernaamste taak as liturg verbrou.

Oor die leiding van die erediens as geheel val daar egter nog een-enander te sê. Hieroor geld 'n drieledige stelreël. 'n Verantwoorde liturgie geskied -

(a) in gehoorsaamheid aan die Bybel,

(b) in ooreenstemming met die kerk van alle tye en

(c) in verantwoordelikheid vir die hede.

(a) In gehoorsaamheid aan die Bybel:

In die Bybel vind ons geen uitgewerkte liturgie nie. Tog bevat die Bybel vir ons alles wat vir ons nodig is vir 'n christelike erediens. Ons hoef nie buite die Bybel daarvoor te soek nie.

Enkele opmerkings moet gemaak word na aanleiding van hierdie stelling:

(i) Votum en groet het die doel om die eredienste te open en moet daarom betrekking hê op die aarde en doel van die gemeentelike samesyn. Geskikte tekste hiervoor is Rut. 2:4; Ef. 2:1; Rom 1:7; Joh. 20:19 en Op. $1: 4$ en 5 waarvan ons bekende trinitariese formule in verkorting is, Ps. 121:2 en 124:8 (wat Calvyn gebruik het) en Ps. 43:3. Deur die gebruik van sulke tekste word willekeur en sentimentaliteit bekamp. 'n Votum wat ontleen is aan die radiowese is absoluut onaanvaarbaar, omdat die erediens nie 'n hoë frekwensie-uitsending is nie, maar gesprek tussen God en Sy gemeente.

(ii) Die formules voor die wetlesing en geloofsbelydenis.

Dit verbaas my altyd weer dat ons hierdic vrye formules so algemeen gebruik, terwyl ons beter tekste het soos bv. Ps. 119:10-12 of slegs net vers 12 en Rom. 10:9 en 10.

(b) In ooreenstemming met die kerk van alle tye:

Ons bely die eenheid van die Kerk op alle plekke en in alle tye. 
Daarom moet ons kennis neem van die liturgie van ander kerke, ander plekke en tye. Hier kan ons egter nie oorneem sondermeer nie. Ons kan alleen gebruik wat nie strydig is met die Skrif en die belydenis van die Kerk nie.

Daar is nie liturgiese besinning in ons Kerk nie. En die paar liturgiese bepalings in ons Kerkwet getuig ook nie altyd van besinning oor die teologiese agtergronde van die liturgie nie. Ons Kerk het ons predikante in hierdie opsig aan hulle lot oorgelaat. Ons huidige liturgie, veral by ons aanddienste toon duidelike tekens van die vrysinnigheid. Die handhawing van so 'n liturgie is nie te rym met ons belydenis nie. Predikante mag ook nie elkeen na sy eie goeddunke handel en verander nie. In die erediens gaan dit om die diens van die Kerk. Daarom moet hierdie saak langs kerklike bane in orde kom. En hopelik sal dit ook met die te verskyne diensboek. Tog mag hierdie werk ook nie saak van 'n kommissie wees nie. Dit is saak van ons Kerk en ons predikante sal positief moet deelneem aan hierdie dinkwerk.

\section{(c) In verantwoordelikheid vir die hede:}

Dit is 'n reformatoriese uitgangspunt dat die dinge wat nie hoorbaar en verstaanbaar is vir die gemeente, nie plek het in die erediens nie. Nou sal dit egter nie baat om links en regs uit te gooi met die verskoning: verstaan nie! Dit sal ook nie baat om net by te neem nie. Vanweë sekere sektariese praktyke sal ons tans gladnie weer die amen van die gemeente en die vredeskus as liturgiese elemente kan invoer nie - terwyl 'n selfstandige skuldbelydenis vir my werklik noodsaaklik lyk. Dit sal niks baat om die liturgie genadeloos skraal of moddervet te mak nie. As die gemeente dit nie kan beleef as diensbetoon aan God nie, is alles nutteloos. In verantwoordelikheid vir ons dag moet die predikant as liturg sy gemeente help om die liturgie te verstaan en beleef as diens van God.

Hierby nog twee terloopse opmerkings:

(i) Ons formuliere ens. Ons Kerk het variante verkorte formuliere afgekeur. Die bestaandes word ook nie taalkundig-stillisties hersien nie. Dit is nie verantwoord nie. En dit het nou tot gevolg die ongehoorde ding $\mathrm{nl}$. dat sommige van ons predikante die gewysigde formuliere van die N.G. Kerk gebruik (tenminste die huweliksformulier).

(ii) Ons Gesangbundel is geen prinsipieël-afgeslote kanon en mag ook nooit as een beskou word nie. Daar is werklike behoefte aan 'n uit. breiding van die Gesangbundel daarom kom daar m.i. telkens weer versoeke dat die Gesangbundel angevul moet word deur 'n geskikte liederebundel. Ek dink as ons verantwoordelik wil handel dan moet ons ernstige oorweging skenk aan uitbreiding van ons Gesangbundel. Selfs die Geref. Kerk in Holland het hierdie behoefte gevoel en aan die begin van hierdie 
jaar in samewerking met die Hollands Herv. Kerk 'n 150 Gesange in ge' bruik geneem.

Hier wil ek verder net noem dat ek dit as absoluut onverantwoord beskou as die Halleluja-bundel of 'n keur van Hallelujaliedere in ons Sondag. skole gebruik word. Dit kan ek nie waardeer as 'n poging van 'n predikant om die gemeente te leer om die liturgie te verstaan en te beleef as diens van God nie.

Ten slotte: die liturgiese taak van die predikant is baie belangrik. Dit is sy verantwoordelikheid om toe te sien dat die aardse gebroke godsdiens in die erediens op die beste wyse vervul word.

\section{KATEGESE EN DIE GEESTELIKE VORMING VAN DIE JEUG:}

Die kategetiese arbeid word om tweërlei rede verrig:

(i) Dit beoog die vermeerdering van kennis in sake die Skrif en die belydenis van die Kerk, en

(ii) die vorming van die lewe van die jeug van die Kerk vir die diens van God.

Prinsipiëel staan dit vas dat dic kategese te doen het met dieselfde evangelie as dié wat oral verkondig moet word (Luk. 1:4). En nou word hierdie werk met sy tweeledige doelstelling toevertrou aan die predikant in medewerking met die ouderling. Hoe moet hierdie samewerking verstaan word? Soms word dit so verstaan : Die ouderling doen die werk. En dan die laaste 14 dae voor die geloofsbelydenis dan vra die predikant uit dieselfde hoekie presies dieselfde vrae. Afgesien daarvan dat dit strydig is met die Kerkwet, is dit geen samewerking nie, maar sinlose duplisering van wat die ouderling reeds gedoen het.

'n Enkele opmerking oor die metodiek van die kategese kan miskien lig werp op hierdie vraag. Die kategetiese metode is naamlik dié van vraag en antwoord. Dit kan op tweërlei wyse geskied:

(i) Die Kort Begrip-metode. Die kategeet vra die vrae en die katkisant antwoord. Hier val die klem op die feit dat die katkisant iets moes leer, naamlik die korrekgeformuleerde vrae en antwoorde. Die nut daarvan is dat die katkisant iets leer en 'n vaste kennis opbou van korrekte formuleringe wat hom kan bewaar van dwaling en kettery. Die gevaar hier is egter die oorbeklemtoning van feitekennis ten koste van die verstaan van die feite. Die taak van die kategeet kan maklik misverstaan word as bloot 'n saak van vasstelling of die katkisant sy werk geleer het aldan nie. Hiervoor is die predikant nie nodig nie. Enigiemand wat goed genoeg kan lees, kan dit doen.

(ii) Die Calvyn-metode: Die katkisant vra vrae en dit kategeet antwoord. Die klem val op die feit dat die katkisante die oningeligtes en 
onmondiges is wat ingelig moet word. Die weg wat gevolg is, is dat die kategeet vooraf 'n les gee en die katkisante dan verduideliking vra. Hier val die klem swaar op die verstaan en die feitekennis kan verwaarloos word. En albei is nodig.

Die regte metode is m.i. ' $\mathrm{n}$ kombinasie van hierdie twee metodes. Dit sal dan so verloop: 'n Les moet gegee word. Feitekennis moet getoets word en uitleg en verduideliking van die feite moet gegee word. Dan vind ons die regte samewerking tussen ouderling en predikant. Die toets van feitekennis lê m.i. in lyn met die ouderling se opsig-tak en die verduideliking lê in lyn met die predikant se teologiese skoling en sy taak om uitleg te gee van die evangelie en mense in te lei in die verborgenhede van die geloof. Daar kan egter nooit 'n skerp skeiding aangebring word tussen dit amptelike werksaamhede nie. Maar langs hierdie weg van onder. skeiding kan die gesamentlike taak van predikant en ouderling miskien die beste tot sy reg kom. Langs hierdie weg kan ons miskien ook daarin slaag om ortodokse gelowiges te vorm. Ortodoksie beteken dat die regte leer gehandhaaf word en dat die regte lofprysing aan God sal toekom. Langs hierdie weg mag daar hopelik ook 'n einde kom aan dié verskynsel dat talle jongmense geloof bely en dat later slegs $19 \%$ van hulle getroue kerkgangers word. Maar, dan sal veral die predikant as kategeet moet onthou dat kategese selfs in die tyd van die Ou Testament al (vgl. Deut. 6:7) persoonlike onderrig was en dan sal hy nooit mag toclaat dat in sy gemeente 'n klein vaal boekie dié kategeet moet wees nie.

Maar hier het ons dan aangekom by dié punt waar ons moet begin praat oor -

VII. DIE HERDERLIKE TAAK VAN DIE PREDIKANT... (Ook bekend as nasorg, sielsorg, huisbesoek, e.d.m.).

Onder hierdie hoof wil ons ter sprake bring vier sake wat deur Art. 1 genoem word, naamlik herderlike sorg (huisbesoek), die sieketroos, die opsig en die arbeid onder dié wat van die Evangelie vervreemd is.

\section{(a) Herderlike sarg en sieketnoos:}

Die Kerkwet makk 'n onderskeid tussen herderlike sorg en sieketroos, want daar word bepaal dat herderlike sorg ingesluit is onder dié werk wat in medewerking met die ouderling moet geskied, terwyl die sieketroos uitgesluit is uit hierdie samewerking. Wat die Kerkwet verstaan onder sieketroos in onderskeiding van herderlike sorg is nie heeltemaal duidelik nie. Miskien word daaronder verstaan die voorbidding vir die siekes. Selfs dan nog is dit nie duidelik waarom dit uitgesluit word onder die herderlike sorg nie en ook nie waarom dit uitgesluit word uit die samewerking tussen ouderling en predikant nie. Die bepalings van die Kerkwet is nogal opvallend in hierdie verband. Die Kerkwet vereis dat predikant 
en diaken die sieketroos behartig, maar by die bepalings vir die presbiteraat word oor sieketroos geen woord gerep nie (vgl. Hoofstuk XVI en XVII, artikels 1). Skynbaar oordeel die Kerkwet dat sieketroos nie die werk van die ouderling is nie. So 'n oordeel is egter in stryd met Jak. 5:14: "Is daar iemand siek onder julle? Laat hom die ouderlinge van die gemeente inroep en laat hulle oor hom bid ...." Ons sluit vir ons doel sieketroos in onder die herderlike sorg.

\section{(b) Herderlike sorg:}

Eerstens moet ons daarop wys dat die reformatoriese vadere die herderlike sorg in 'n ernstige lig beskou het. So vroeg as 1538 al het Bucer 'n werkie "Von der wahren Seelsorge" uitgegee. Calvyn het die huisbesoek tot vaste taak van predikant en ouderling gemaak. Dit het langs die prediking in die kerk bestaan as 'n gesprek waardeur die evangelie aan die enkeling gebring is.

Tog was daar in die reformatoriese kerk afwyking in twee rigtings. Brillenburg Wurth (Verkondiging en Zielzorg) wys daarop dat die enkeling verindiwidualiseer en verpsigologiseer is. Dit het dan uitgeloop op ' $n$ oorskatting van die sielsorg ten opsigte van die prediking. (Dit kom in ons Kerk ook voor. Al wat dan tel is die vraag hoeveel huisbesoek die predikant gedoen het al gaan dit dan Sondae op die kansel nie so goed nie. Dit maak nie groot saak nie). Verder wys Wurth ook op 'n oorskatting van die prediking ten opsigte van die sielsorg. Hierby word vergeet dat die gemeente gebou word met lewende mense as die boustene (I Petr. 2:5).

(Hierdie verskynsel kom ook by ons Kerk voor. Dan word herder. like sorg nagelaat en die enkeling onder gebring onder die groep).

Om herderlike sorg reg te verstaan is nodig 'n regte verstaan van die verhouding enkeling-gemeente - so soos I Petr. 2:5 die verhouding stel. Ons moet die enkeling sien in sy „.... verantwortliche Person-sein vor Gott ...." (Thurneysen p. 51) of soos Natan vir Dawid aangespreek het: „Jy is die man". Verder is nodig 'n regte verstaan van die doel van die herderlike sorg. Dit sny Paulus aan - juis in samehang met die prediking — in Hand. 20:20: ". . . hoe ek niks teruggehou het van wat nuttig is nie om dit aan julle te verkondig en julle te onderrig in julle huise en in die openbaar nie".

Die teks word soms uitgelê dat Paulus in die openbaar (op die mark. plein) en in die huise (die bokamer - Hnd. 20:8) gepreek het. Dit doen nie reg aan die teks nie. Paulus self gebruik die twee begrippe ananggeilai en didaksai. Dit kan ons miskien die beste vertaal met „om te preek" en „om te onderrig". Vervolgens moet daarop gewys word dat die Afrikaanse vertaling kat' oikous ten onregte vertaal met ,in julle huise". Die sin van die uitdrukking is tog eintlik ,van huis tot huis" 
(vgl. in Hnd.. 2:46 die uitdrukkinge kath' hemeran en kat' oikous). Word in gedagte gehou dat Hnd. 20 Paulus se afskeidstoespraak te Efese weergee, dan word duidelik dat Paulus hier die twee tipes werk wat hy in die gemeente verrig het, vermeld. As sy oproep in vers 28 dat die ouderlinge die kudde van die Heer moet poimainein, ook hierin mag meespreek, dan is dit duidelik dat Paulus in vers 20 praat oor sy preekwerk en sy herderlike sorg aan die gemeente bestee. Hierdie vermoede word verder versterk as Paulus se pastorale bewoënheid in herinnering geroep word. Paulus het bv. by elke sendingreis weer op sy voetspore teruggegaan om die broeders te versterk. Al sy briewe getuig van dieselfde bewoënheid wat betuig word in Hnd. 15:36: "Laat ons teruggaan en ons broeders besoek in al die stede waar ons die Woord van die Here verkondig het, om te sien hoe dit met hulle gaan".

Ons kan nou sê dat die herderlike sorg nasorg is met 'n onderrig. karakter wat voortkom uit die feit dat mense dissipels geword het en om dissipels te kan wees, in die Woord wat hulle gehoor het, moet bely. (Joh. $8: 31)$. Die werk rig hom op die gemeente as geheel en op die enkele gelowige ,sodat nie één van dié wat God gegee het verlore mag gaan nie" en God deur almal in die openbaar en van huis tot huis gedien kan word. En dit sê ons met twee uitsprake van Jesus Christus in gedagte, naamlik Mat. $8: 38$ : ,Want elkeen wat hom skaam vir My en My woord in hierdie sondige en oorspelige geslag, vir hom sal die Seun van die mens Hom ook skaam ...." en Mat. 6:6: „Maar jy wanneer jy bid gaan in jou binnekamer...". Hierdie herderlike sorg rig hom op die onderhouding van die openbare sowel as private gedeelte van die Godsdiens. Die openbare gedeelte kom tot sy reg in die getuienis teenoor almal met wie die gelowige in aanraking kom (Hnd. 1:8) en in die getroue onderhouding van die openbare erediens (Heb. 10:23-27) en die private gedeelte in die getroue onderhouding van die huisgodsdiens (Mt. 6:6). Die herderlike sorg wil hiervoor sorg deur elke gelowige as verantwoordelike mens te onderrig en aan te spreek, daar waar hy hom bevind. (H. Asmussen: Seelsorge bl. 15).

\section{(iii) Herderlike sorg en opsig:}

Die opsig word onderskei van die herderlike sorg. Geskei mag dit nie word nie. Nasorg mak opsig onvermydelik. Soos troos en onderrig 'n deel is van nasorg, so kan ons sê is die opsig die ander kant. Dit is juis herderlike sorg wat opsig uiteindelik laat oorgaan in tug. Dit word duidelik as ons tug verstaan as toegespitste herderlike bearbeiding van die enkeling. Die tug word op die enkeling toegepas ten einde hom by die Woord te hou, maar tegelyk ook terwille van die geestelike welsyn van die gemeente. By die tug kan die enkeling nie verindiwidualiseer word nie, hy kan ook nie opgelos word in die massa nie. Hy bly lewende bousteen wat ingebou moet word in die lewende Godsgebou, waarin daar 
nie dooie stene kan wees nie, want dit moet 'n tempel wees waarin God kan woon deur Sy Gees.

\section{(iv) Herderlike sorg en arbeid aan die evangelisevervreemdes:}

Iemand wat van die evangelie vervreemd is, is iemand wat die evangelie gehoor en aanvaar het, moontlik ook geloofsbelydenis afgelê het, maar later vir alle praktiese redes buite die kerklike gemeenskap gaan staan het en nie meer die openbare of private deel van die godsdiens onderhou nie. As die herderlike sorg wel die enkeling as verantwoordelike mens moet aanspreek, dan het ons predikante juis hier 'n groot taak. Ons erediens bywoning is maar $19 \%$ en avondmaalsbywoning slegs $36 \%$. Daar is talle gedooptes wat nooit belydenis doen nie en baie kinders uit gelowige ouers gebore wat nooit gedoop word nie. Die getalle evangelievervreemdes is groot en neem nog steeds toe. Die herderlike sorg sal hier die volle siklus moet deurloop: troos, onderrig, en uiteindelik tug, want hierdie werk moet onderneem word in direkte gehoorsaamheid aan Mat. 28:19(b) ".... leer hulle om alles te onderhou wat Ek julle beveel het".

\section{(v) Praktiese opmerkings:}

Huisbesoek moet pligsgetrou gedoen word in die gestaltes van onderrig en opsig oor die enkeling. Die Bybellesing en gebed is hierby seker op sy plek, maar die ander mag nie agterweë bly nie.

Dit moet sistematies gedoen word. 'n Bruikbare skema blyk te wees die drie belydenisvrae waarop ,,ja" geantwoord is.

Dit Kerkwet Hoofstuk IX, Art. 1, bladsy 42 bepaal: „Die kategese het tot doel om lede van die Kerk en hulle wat tot die Kerk wil toetree, voor te berei vir die openbare belydenis van die geloof, vir deelname aan die heilige sakramente en vir aanvaarding van medeverantwoordelikheid vir die opbou van die Godsryk in die algemeen en die Ned. Hervormde Kerk in die besonder". Al hierdie dinge het 'n repeterende, duratiewe karakter: Elke Sondag doen die gemeente openbare geloofsbelydenis, telkens opnuut vier ons die sakramente en voortdurend moet ons werk aan die opbou van die Kerk. Daarom lyk dit aangewese dat ons ná die eerste openbare belydenis en avondmaalsviering maar nog moet voortgaan met katkisasie. Daarom skyn dit 'n baie groot deel van die predikant se kategetiese taak te wees om voortgesette kategese te behartig deur bybelstudieaande, ander groepbyeenkomste, doops. en huwelikskate. gese.

Die werk moet gedoen word in noue samewerking met die ouderling en deur oorlegpleging met mekaar.

Die lidmate mag nie sonder die nodige onderrig getug word nie. Dit 
is net so verkeerd as die tug na geduldige onderrig by blyke van volharding in die sonde, nie toegepas word nie.

Dit is verkeerd as die predikant mense dreig met die hel oor hulle versuim van die erediens en huisgodsdiens as hy hulle nie eers behoorlik onderrig het aangaande die pretensies en betekenis van erediens en huis godsdiens nie.

Die sakramente mag nie geweier word nie tensy mense reeds onder tug staan of daar reeds tughandelinge met hulle aangeknoop is.

Die sieketroos bied 'n groot taak. Ten eerste moet die kerkwetbepalings hieroor reggestel word en tweedens: Ons lidmate se houding tydens siekte is dikwels die grofste verloëning van die geloof wat Paulus in Rom. 14:8 verwoord: „Want as ons lewe, leef ons tot eer van die Here en as ons sterwe, sterf ons tot eer van die Here; of ons dan lewe en of ons sterwe, ons behoort aan die Here". Ons sieketroos sal dikwels die skerp vraag moet wees: „Hoe is julle dan so bang? Het julle dan geen geloof nie?" (Mk. 4:40).

Wanneer herderlike werk goed gedoen is dan het dit die uitwerking dat dié aan wie dit bestee is, self herdelik bewoë van harte gewillig en bereid word om Mat. 18:15.17 na te lewe: „As jou broer sondig . ..."

Ten slotte is dit nou goed om te luister na wat ds. J. Overduin sê: „De huisbezoeker kan niets van zich zelf en degene dié bezocht werd, kan niets van zich zelf. Alles moet God doen, alles moet God geven. En ook het geloof dat dit zóó is en dat dit ons uitgangspunt moet zijn, moet God geven”. En dan verder: „Dit enig-juiste uitgangspunt des geloofs sluit nu alle hoogmoed en tegelijk alle moedeloosheid uit. Hoogmoed en moedeloosheid gaan samen. Wanneer wij in eigen kracht arbeiden en het verwachten van ons inzicht onze menschenkennis, onze routine, onze liefde, ons geduld en onze mooi methode waarmee we zoveel succes' hadden, dan worden we hoogmoedig, dan maken we ons schuldig aan afgodendienst, door van al die op zich zelf goede en onmistbare dingen iets te gaan verwachten; dat we alleen van Gods Geest en Woord mogen verwachten. Dan dienen psychologie en metode niet meer, maar dan heerschen zij. Dan loopen we heel erg gevaar meer afhanklijk te zijn van, en ons meer sterk te gevoelen in onze methoden dan in den Heere onze God, Die alleen een ,steenen hart' kan wegnemen en een, vleezen hart' kan schenken. $\mathrm{U}$ begrijpt nu wat ik bedoel, we mogen het schepsel (in ons geval: de sielkunde; de methode, de ijver, de trouw) nooit de plaats geven van den Schepper. De Schepper moet ons beheerschen en het schepsel mag dienen".

Herderlike sorg mag niks anders wees as gestalte van die Woordverkondiging nie. 
Die Kerkwet plaas die predikant in die voorsitterstoel. Dit is nie so in alle kerke nie. Prinsipiëel hoef dit ook nie so te wees nie. Miskien is dit goed, miskien ook nie. Hieroor net twee opmerkings:

(a) Die een amp is nie meer as die ander nie. Die een amp mag ook nie die ander verplaas of vervang nie. In praktyk beklee ons predikante feitlik alleen al drie die ampte. Die kerkraadsvergadering veral is ' $n$ goeie geleentheid vir die predikant om' 'n diens te bewys aan die ander amps. draers. Hy kan hulle daar so toerus vir hulle dienswerk deur sy leiding in die vergadering, dat die gemeentelewe vanuit die vergadering ' $\mathrm{n}$ vorm en gestalte kan ontvang waardeur God gedien en verheerlik kan word.

(b) Die predikant moet die amptelike vergadering lei. Dit is 'n bose dag vir 'n gemeente as 'n predikant die voorsitterstoel neutraal beset. Leiding gee is baie meer as orde handhaaf. Die voorsitter kan ook 'n vergadering oordonder sodat die lede van die vergadering die twyfelagtige voorreg het om die voorsitter se besluite onder hulle naam te laat notuleer. Leiding is ook iets anders as dit. Dit is die weg wys sodat die vergadering verantwoord kan handel en besluit en hom steeds mag bevind op die weg van gehoorsaamheid aan die Woord. As die predikant so voorsit, dan is dit goed dat hy die stoel ontvang het.

\section{TEN SLOTTE:}

Die predikant se ganse werk is gerig op die opbou van die gemeente. Die gemeente-opbou is ' $n$ saak van toeneem in getalle en in geloof. In ons kerk raak jaarliks plus-minus 1,000 belydende lidmate weg. Die kerkbesoek is $19 \%$. Oral is traagheid en onverskilligheid op te merk. Ons sê dikwels ons predikante preek so mooi en werk so goed en tog kom die gemeenteopbou nie tot sy reg nie. Ek meen, dat ek deur positief te stel wat die predikant in die gemeente moet „doen", ook 'n aanduiding verskaf het van wat hy nie mag nie. Hy moet slegs die Woord bedien in al die gestaltes waarin die Woord bedien wil word. Dit is sy diakonia wat hy as diakonos van God vir die gemeente moet verrig. Al die ander dinge is bysaak. 